Letter to the Editor

\title{
KRAS mutation in colorectal cancer metastases after adjuvant FOLFOX for the primary
}

\author{
J-N Vauthey*,', S Kopetz², TA Aloia' and A Andreou' \\ 'Department of Surgical Oncology, The University of Texas MD Anderson Cancer Center, 1515 Holcombe Boulevard, Unit I 484, Houston, TX 77030, \\ USA; ${ }^{2}$ Department of Gastrointestinal Medical Oncology, The University of Texas MD Anderson Cancer Center, 1515 Holcombe Boulevard, Unit 426, \\ Houston, TX 77030, USA
}

British Journal of Cancer (2012) I 07, |442-|443. doi:I0.1038/bjc.2012.419 www.bjcancer.com

Published online 27 September 2012

(c) 2012 Cancer Research UK

Sir,

We read the article by Kawamoto et al (2012) entitled 'KRAS mutations in primary tumours and post-FOLFOX metastatic lesions in cases of colorectal cancer' with great interest. This study examined KRAS, NRAS, BRAF and PIK3CA mutations in 21 patients who were treated with FOLFOX as adjuvant therapy for stage III/IV colorectal cancer following curative resection. The authors showed that the mutational status of KRAS remained concordant between the primary tumours and the post-FOLFOX metastatic lesions, irrespective of patient background, treatment duration and disease-free survival (DFS). This study also suggested that KRAS mutation rates were significantly higher in lung than in liver metastases as previously shown (Tie et al, 2011).

We congratulate the authors for studying somatic gene mutations after adjuvant treatment of colorectal cancer with FOLFOX. However, an important question that arises from this study is why most patients who recurred after FOLFOX treatment had mutations (17 out of $21 ; 81 \%$ ), whereas only a small number of patients were noted to have wild-type tumours ( 4 out of $21 ; 19 \%$ )? This is much lower than would have been expected, based on the 35-40\% KRAS mutation rates reported in primary tumours (Andreyev et al, 1998).

We have recently analysed the outcome of patients undergoing resection of metachronous colorectal liver metastases (CLM) after

\section{REFERENCES}

Andreou A, Kopetz S, Maru DM, Chen SS, Zimmitti G, Brouquet A, Shindoh J, Curley SA, Garrett C, Overman MJ, Aloia TA, Vauthey JN (2012) Adjuvant chemotherapy with FOLFOX for primary colorectal cancer is associated with increased somatic gene mutations and inferior survival in patients undergoing hepatectomy for metachronous liver metastases. Ann Surg 256: 642-650

Andreyev HJ, Norman AR, Cunningham D, Oates JR, Clarke PA (1998) Kirsten ras mutations in patients with colorectal cancer: the multicenter 'RASCAL' study. J Natl Cancer Inst 90: 675-684

Etienne-Grimaldi MC, Cardot JM, Francois E, Renee N, Douillard JY, Gamelin E, Milano G (2008) Chronopharmacokinetics of oral tegafur and uracil in colorectal cancer patients. Clin Pharmacol Ther 83: 413-415

Italiano A, Hostein I, Soubeyran I, Fabas T, Benchimol D, Evrard S, Gugenheim J, Becouarn Y, Brunet R, Fonck M, Francois E, Saint-Paul MC, Pedeutour F (2010) KRAS and BRAF mutational status in primary

*Correspondence: Dr J-N Vauthey; E-mail: jvauthey@mdanderson.org

Published online 27 September 2012 adjuvant chemotherapy with FOLFOX for primary stage III colorectal cancer (Andreou et al, 2012). This analysis indicated that patients treated with FOLFOX after resection of colorectal cancer had lower survival and an increased rate of KRAS mutations in CLM compared with patients treated with 5-FU only. DFS and overall survival (OS) rates after hepatectomy were worse in patients treated with adjuvant FOLFOX (DFS at 3 years: $14 \%$ vs $38 \%$ (5-FU) $(P<0.0001)$, OS at 3 years: $58 \%$ vs $70 \%(5-\mathrm{FU})$ $(P=0.036))$. Mutation analysis of liver resection specimens revealed KRAS mutations in $47 \%$ of patients after FOLFOX, and only $22 \%$ after 5 -FU $(P=0.015)$. Thus, our study suggested that adjuvant FOLFOX may provide a selection pressure favoring a chemotherapy-resistant subset enriched for KRAS mutations while on balance, preventing liver recurrences of patients with KRAS wild-type primary tumours.

Therefore, the high rate of KRAS mutations after adjuvant FOLFOX therapy in this and in our study suggests that although Kawamoto et al (2012) confirm that there is concordance of KRAS mutational status between primary and metastatic lesions (Oudejans et al, 1991; Etienne-Grimaldi et al, 2008; Santini et al, 2008; Italiano et al, 2010; Knijn et al, 2011), there might be discordance of KRAS mutational rates because of the selection of a more aggressive form of metastatic disease as a result of therapy.

colorectal tumors and related metastatic sites: biological and clinical implications. Ann Surg Oncol 17: 1429-1434

Kawamoto Y, Tsuchihara K, Yoshino T, Ogasawara N, Kojima M, Takahashi M, Ochiai A, Bando H, Fuse N, Tahara M, Doi T, Esumi H, Komatsu Y, Ohtsu A (2012) KRAS mutations in primary tumours and post-FOLFOX metastatic lesions in cases of colorectal cancer. Br J Cancer 107: 340-344

Knijn N, Mekenkamp LJ, Klomp M, Vink-Borger ME, Tol J, Teerenstra S, Meijer JW, Tebar M, Riemersma S, van Krieken JH, Punt CJ, Nagtegaal ID (2011) KRAS mutation analysis: a comparison between primary tumours and matched liver metastases in 305 colorectal cancer patients. Br J Cancer 104: 1020-1026

Oudejans JJ, Slebos RJ, Zoetmulder FA, Mooi WJ, Rodenhuis S (1991) Differential activation of ras genes by point mutation in human colon cancer with metastases to either lung or liver. Int J Cancer 49: 875-879

Santini D, Loupakis F, Vincenzi B, Floriani I, Stasi I, Canestrari E, Rulli E, Maltese PE, Andreoni F, Masi G, Graziano F, Baldi GG, Salvatore L, Russo A, Perrone G, Tommasino MR, Magnani M, Falcone A, Tonini G, Ruzzo A (2008) High concordance of KRAS status between primary 
colorectal tumors and related metastatic sites: implications for clinical practice. Oncologist 13: 1270-1275

Tie J, Lipton L, Desai J, Gibbs P, Jorissen RN, Christie M, Drummond KJ, Thomson BN, Usatoff V, Evans PM, Pick AW, Knight S, Carne PW, Berry
R, Polglase A, McMurrick P, Zhao Q, Busam D, Strausberg RL, Domingo E, Tomlinson IP, Midgley R, Kerr D, Sieber OM (2011) KRAS mutation is associated with lung metastasis in patients with curatively resected colorectal cancer. Clin Cancer Res 17: 1122-1130 